\title{
Penggunaan Daluwarsa sebagai Dasar Permohonan Praperadilan di Indonesia: Antara Formil atau Materiil
}

\author{
Peter Jeremiah Setiawan, ${ }^{1}$ Xavier Nugrah, ${ }^{2}$ Moch. Marsa Taufiqurrohman ${ }^{3}$ \\ ${ }^{1}$ Universitas Surabaya, ${ }^{2}$ Universitas Airlangga, ${ }^{3}$ Universitas Jember \\ Email: peterjsetiawan@staff.ubaya.ac.id
}

\begin{abstract}
Abstrak
Artikel ini bertujuan untuk menjawab apa yang menjadi ruang lingkup praperadilan di dalam peraturan perundang-undangan danapakah daluwarsa dapat digunakan sebagai alasan mengajukan permohonan praperadilan. Dengan menggunakan metode penelitian hukum melalui pendekatan peraturan perundang-undangan, konseptual, dan kasus. Artikel ini berkesimpulan, tidak adanya kategorisasi yang jelas terkait dengan aspek formil dan materiil pada kasus daluwarsa menimbulkan dilematika. Dalam perkembangannya, daluwarsa mulai diakui sebagai alasan formil yang notabene tidak menyentuh pokok perkara, sehingga dapat digunakan sebagai alasan praperadilan. Hal ini dapat dilihat dalam Putusan Praperadilan Nomor: 143/Pid.Prap/2016/PN.Jkt.Sel. Puncaknya, artikel ini menyarankan perlunya pengaturan yang jelas di dalam Perma terkait kategorisasi aspek formil dan materiil di dalam pemeriksaan praperadilan.
\end{abstract}

Kata Kunci: Daluwarsa; Hukum Formil; Praperadilan; Hukum Materiil.

\section{Abstract}

This article aims to answer what is the scope of pretrial in statutory regulations and whether expiration can be used as an excuse to file a pretrial lawsuit. By using legal research methods through statutory, conceptual, and case-based approaches, this article concludes that the absence of a clear categorization regarding the formal and material aspects of the expiration case creates a dilemma. In its development, expiration has begun to be recognized as a formal reason which incidentally does not touch the subject matter of the case, an thus can be used as a pretrial excuse. This can be seen in the Pre-trial Decision Number: 143/Pid.Prap /2016 /PN.Jkt.Sel. Ultimately, this article suggests the need for a clear regulation in the Perma regarding the categorization of formal and material aspects in pretrial hearings.

Keywords: Expiration, formal law, pretrial hearing, material law.

\section{Sejarah Artikel}

Dikirim: 10 September 2020

Direview: 28 November 2020

Diterima: 31 Desember 2020

Diterbitkan: 31 Desember 2020

\section{PENDAHULUAN}

Diskursus mengenai idealitas penyelenggaraan pranata praperadilan menghantarkan kita kepada evaluasi terhadap setiap ruang lingkup maupun objek praperadilan sebagai sebuah entitas yang dalam perkembangannya dapat terus tumbuh dan 
berkembang. Episode-episode perkembangan ruang lingkup praperadilan terlihat dalam beberapa kasus. Misalnya, pada awal tahun 2015, ketika Budi Gunawan yang menggugat penetapan tersangka oleh Komisi Pemberantasan Korupsi (KPK) kepada praperadilan. Praperadilan dalam kasus ini menyatakan bahwa penetapan tersangka oleh KPK adalah tidak sah. ${ }^{1}$ Hakim praperadilan dalam kasus ini memperluas objek praperadilan di luar ketentuan Kitab UndangUndang Hukum Acara Pidana (KUHAP) dengan mengartikan penetapan tersangka sebagai bagian dari upaya paksa. Hakim praperadilan dalam kasus ini juga "mengamini" dalil Budi Gunawan yang menyatakan bahwa dalam proses penyelidikan ia tak pernah dimintai keterangan. ${ }^{2}$ Padahal penyelidikan bertujuan mengumpulkan bukti permulaan yang cukup untuk menetapkan tersangka, sekurang-kurangnya dua alat bukti. Sehingga dalam proses penyelidikan, KPK maupun penyidik tak harus meminta keterangan saksi. ${ }^{3}$

Tidak lama kemudian, pada 28 April 2015 Mahkamah Konstitusi (MK) mengeluarkan Putusan No. 21/PUU-XII/2014 yang memperluas pengertian objek praperadilan dengan menyatakan penetapan tersangka, penyitaan dan penggeledahan termasuk sebagai objek praperadilan. Kemudian atas putusan MK tersebut, Mahkamah Agung mengeluarkan Peraturan Mahkamah Agung Nomor 4 Tahun 2016 (Perma No.4/2016) mengenai tentang larangan peninjauan kembali atas putusan praperadilan.

\footnotetext{
${ }^{1}$ Ely Kusumastuti, "Penetapan Tersangka Sebagai Obyek Praperadilan," Yuridika, 33, no. 1 (2018): 2.

2 Putusan

Nomor:

04/Pid.Prap/2015/PN.Jkt.Sel.

${ }^{3}$ Chandra M. Hamzah, "Penjelasan Hukum (Restatement) tentang Bukti Permulaan Yang Cukup," 2014, 48.
}

Episode-episode di atas menunjukkan, bahwa ruang lingkup praperadilan semakin berkembang. Perkembangan tersebut menjadi tidak dapat dimungkiri, apabila perluasan ruang lingkup praperadilan berkaitan erat dengan perlindungan hak asasi tersangka maupun kepastian hukum itu sendiri.

Pada hakikatnya, hukum acara pidana adalah aturan hukum untuk melindungi warga negara dari perlakuan sewenangwenang oleh aparatur penegak hukum. ${ }^{4}$ Hakikat keberadaan pranata praperadilan adalah sebagai bentuk pengawasan dan mekanisme keberatan terhadap proses penegakan hukum yang terkait erat dengan jaminan perlindungan hak asasi manusia (HAM). Praperadilan yang ada pada KUHAP yang dianggap dapat memberikan perlindungan HAM secara substantif, kemudian membuat pada zamannya, aturan tentang praperadilan dianggap sebagai bagian dari mahakarya KUHAP. ${ }^{5}$

Het recht hink achter de feiten aan, sebuah psotulat hukum klasik yang memiliki makna, bahwa sejatinya hukum akan selalu tertinggal dengan perkembangan zaman. ${ }^{6}$ Dalam perjalanannya ternyata dalam lembaga praperadilan terdapat hal yang belum diberikan perlindungan, yaitu pada pra-ajudikasi. $^{7}$ Fungsi pengawasan yang diperankan pranata praperadilan hanya bersifat post facto, sehingga tidak sampai

${ }^{4}$ Gultom dan Sularto, "Ide Dasar Keseimbangan Dalam Penetapan Status Tersangka Sebagai Objek Praperadilan Oleh Kekuasaan Kehakiman Di Indonesia,” 2.

5 Paul Eliezer Tuama Moningka, "Praperadilan sebagai Mekanisme Kontrol terhadap Tindakan Penyidik dalam Menetapkan Tersangka Menurut Putusan Mk Nomor: 21/puu-xii/2014," Lex Crimen 6, no. 6 (2017): 10.

${ }^{6}$ Rachmad Abduh, Ida Hanifah "Certainty of Jurisdiction Law in Civil Law System," Randwick International of Social Science Journal 1, no. 2 (2020): 272.

${ }^{7}$ Putusan MK Nomor 21/PUU-XII/2014. 
pada penyidikan. Pengujian praperadilan pada akhirnya hanya bersifat formil yang mengedepankan unsur objektif, sedangkan unsur subjektif tidak dapat diawasi pengadilan. ${ }^{8}$ Dengan dasar tersebut, maka lembaga praperadilan secara teoritis, hanya bersifat formil semata, bukan materiil. ${ }^{9}$

Adanya ruang lingkup praperadilan yang terbatas pada ranah formil inilah yang dalam praktiknya sangat bias untuk menginterpretasi mengenai mana yang termasuk pada ranah formil dan materiil. Jika dilihat penyebabnya, maka dapat dipahami bahwa penyebab utamanya adalah karena dalam peraturan perundang-undangan, tidak terdapat definisi / batasan yang jelas mengenai ruang lingkup dari konsep formil. Hal inilah yang kemudian menjadi salah satu hal yang membuat praperadilan menjadi kompleks. Padahal hukum sejatinya, harus dapat mengadopsi tujuan keadilan dan kemanfaatan secara bersamaan sehingga jika kehidupan sosial semakin kompleks maka hukum perlu lebih dikonkretkan secara ilmiah dan menggunakan bahasa yang lebih baik dan sempurna. $^{10}$

Salah satu problematika terkait dengan dilematika antara kategori formil atau materiil adalah dapat dilihat terkait pada daluwarsa. Terkait dengan daluwarsa (verjaring) ini diatur di dalam Pasal 78 Kitab Undang-undang Hukum Pidana (KUHP) yang notabene merupakan batasan waktu untuk penuntut umum untuk melakukan kewenangan penuntutannya. Menurut Eddy

\footnotetext{
${ }^{8}$ Putusan MK Nomor 21/PUU-XII/2014.

${ }^{9}$ Putusan MK Nomor 21/PUU-XII/2014.

10 Sidharta, Pendekatan Hukum Progresif dalam Mencairkan Kebekuan Produk Legislasi, dalam Moh. Mahfud MD, Sidharta, Sunaryati Hartono, dkk, 2013, Dekonstruksi dan Gerakan Pemikiran Hukum Progresif (Konsorsium Hukum Progresif Universitas Diponegoro Semarang) (Thafa Media, 2013), 207-214.
}

OS Hiariej, sejatinya daluwarsa merupakan aspek materiil yang dianggap sudah tidak dibutuhkan lagi pemidanaan dari masyarakat karena melampai waktu. ${ }^{11}$ Namun, terdapat pendapat yang menganggap, daluwarsa merupakan ruang lingkup formil, karena terkait dengan administrasi suatu perkara, bukan materi pokok perkaranya. Dengan dasar tersebut, maka dapat dilihat bahwa terdapat perbedaan pendapat terkait ruang lingkup daluwarsa yang notabene diperdebatkan ranahnya antara materiil atau formil.

Terkait ruang lingkup praperadilan sejatinya telah diatur di dalam Pasal 1 angka 10 KUHAP jo. Pasal 77 KUHAP yang hanya berbeda pada konstruksi perumusan norma saja, maka juga tidak dapat menjawab terkait dengan dilematika ruang lingkup daluwarsa penetapan tersangka. Sehingga penilaian terhadap daluwarsa sebuah tindak pidana untuk dijadikan sebagai aspek formil maupun dasar permohonan praperadilan, masih menimbulkan perdebatan. Hal ini juga terlihat dengan perkembangan ruang lingkup praperadilan yang semakin meluas. ${ }^{12}$ Selain itu, fakta ini juga tersirat dari banyaknya putusan-putusan praperadilan yang mengabulkan di luar daripada objek yang ditentukan di dalam KUHAP. ${ }^{13}$ Artinya, ruang lingkup wewenang praperadilan tetaplah tidak stagnan.

Pembahasan dan diskusi tentang permasalahan tersebut memunculkan beberapa rumusan masalah yang ingin dijawab di dalam artikel ini. Pertama, apa ruang lingkup praperadilan di dalam peraturan perundang-undangan di Indonesia. Kedua, Apakah daluwarsa dapat digunakan sebagai alasan mengajukan permohonan praperadilan.

\footnotetext{
${ }^{11}$ Eddy OS Hiariej, Prinsip-prinsip hukum pidana (Cahaya Atma Pustaka, 2016), 144.

${ }^{12}$ Harjono Tjitrosoebono, 5.

${ }^{13}$ Harjono Tjitrosoebono, 5.
} 
Dalam menjawab pertanyaan tersebut, artikel ini disusun dengan menggunakan metode penelitian hukum dengan pendekatan peraturan perundang-undangan, konseptual, dan kasus. Artikel ini bertujuan untuk menganalisis kembali ruang lingkup praperadilan di dalam peraturan perundangundangan, serta bertujuan untuk menganalisis keabsahan aspek daluwarsa penuntutan pidana yang digunakan sebagai alasan mengajukan permohonan praperadilan.

Terdapat beberapa artikel pada jurnal hukum yang serupa dengan artikel ini, yaitu:

1. Artikel dari Sri Wulandari yang diterbitkan oleh Jurnal Serat Acitya dengan judul "Kajian Tentang Praperadilan Dalam Hukum Pidana". Pada artikel tersebut fokus pembahasannya adalah terkait praperadilan secara umum dalam KUHAP. Perbedaan dengan artikel yang ditulis oleh para penulis adalah dalam artikel dari Sri Wulandari hanya menguraikan secara umum terkait dengan praperadilan, sementara dalam artikel ini fokus analisisnya adalah terkait dengan penggunaan daluwarsa sebagai alasan praperadilan

2. Artikel dari Indah Febriani Kaligis yang diterbitkan oleh Jurnal Lex Crimen dengan judul "Daluwarsa Penuntutan Pidana Ditinjau Dari Pasal 78 Kitab Undang-Undang Hukum Pidana (KUHP)". Pada artikel tersebut fokus pembahasannya adalah terkait dengan daluwarsa dalam KUHP, Perbedaan dengan artikel yang ditulis oleh para penulis adalah dalam artikel dari Indah Febriani tidak membahas terkait dengan akibat hukum dari penetapan tersangka pada delik yang seharusnya sudah daluwarsa, sedangkan pada artikel para penulis akan diuraikan.

3. Artikel dari Ramiyanto yang diterbitkan oleh Jurnal Legislasi dengan judul "Kedudukan Penetapan Tersangka Di Dalam Objek Gugatan Praperadilan". Pada artikel tersebut fokus pembahasannya adalah terkait perluasan konsep objek praperadilan pasca Putusan Mahkamah Konstitusi Nomor 21/PUU-XII/2014. Perbedaan dengan artikel yang ditulis oleh para penulis adalah dalam artikel dari Ramiyanto fokusnya adalah terkait perluasan objek praperadilan yang notabene salah satunya adalah penetapan tersangka, namun tidak diuraikan terkait dengan alasan-alasan yang dapat digunakan sebagai dalil dalam mengajukan praperadilan terkait dengan penetapan tersangaka.

\section{PEMBAHASAN}

\section{Ruang Lingkup Praperadilan di dalam Peraturan Perundang-undangan di Indonesia}

Ad Recte docendum oportet primum inquirere nomina, quia rerum cognitio a nominimbus rerum dependet. ${ }^{14}$ Sebuah postulat hukum klasik yang memiliki kedalaman makna, bahwa untuk memahami suatu konsep hukum, maka harus diawali dari sebuah definisi. ${ }^{\mathbf{1 5}}$ Dengan dasar tersebut, maka untuk memahami ruang lingkup praperadilan, maka harus dipahami terlebih dahulu definisi dari praperadilan itu sendiri. Berdasarkan Pasal 1 angka 10 KUHAP

14 Eddy O.S. Hiariej, Prinsip Hukum Pidana: Edisi Revisi (Yogyakarta: Cahaya Atma Pustaka, 2016), 2.

15 Xavier Nugraha, John Eno Prasito Putra, Krishna Darari Hamonangan Putra, “Analisa Daluarsa Gugatan Pembatalan Perjanjian Akibat Adanya Penyalahgunaan Keadaan (Misbruik Van Omstandigheiden)," Galuh Justisi 8, no. 1 (2020): 60. 
mendefinisikan praperadilan sebagai wewenang pengadilan negeri dalam memeriksa dan memutus sah atau tidaknya suatu penangkapan dan/atau penahanan atas permintaan tersangka atau keluarganya atau pihak lain atas kuasa tersangka. Melalui praperadilan KUHAP juga memberikan wewenang kepada pengadilan negeri untuk memeriksa dan memutus sah atau tidaknya penghentian penyidikan atau penuntutan. Termasuk terhadap permintaan ganti kerugian atau rehabilitasi oleh tersangka.

Praperadilan memiliki maksud dan tujuan untuk menegakkan hukum dan melindungi hak asasi tersangka dalam tingkat pemeriksaan penyidikan dan penuntutan. ${ }^{16}$ Pada dasarnya setiap upaya paksa dalam penegakan hukum mengandung nilai HAM. ${ }^{17}$ Dengan dasar tersebut, maka perampasan atas HAM harus sesuai dengan acara yang berlaku (due process) dan hukum yang berlaku (due of law). ${ }^{18}$ Ditinjau dari standar universal, maupun dalam KUHAP, maka dapat dilihat bahwa tindakan upaya paksa merupakan perampasan HAM atau hak privasi perseorangan (personal privacy right) yang dilakukan penguasa (aparat penegak hukum) dalam melaksanakan fungsi peradilan dalam sistem peradilan pidana (criminal justice system). ${ }^{19}$

${ }^{16}$ Abdul Halim Barkatullah, Praperadilan: Sarana Perlindungan Tersangka dalam Sistem Peradilan Pidana Indonesia (sesudah diedit editor) (Nusa Media, 2020), 105.

${ }^{17}$ M. Irfan Islami Rambe, "Upaya Hukum Terhadap Praperadilan," JURNAL PIONIR 2, no. 3 (2017): 1.

18 Fikri Akbar Hadithna Masrur, "Kewenangan praperadilan dalam memutus sah tidaknya penetapan tersangka dikaitkan dengan prinsip Due Process of Law dalam sistem peradilan pidana Indonesia," 2019, 3.

19 Syafruddin Kalo dan M. Hamdan, "Perluasan Kewenangan Praperadilan Terkait Hakhak Tersangka dalam Konteks Pembaharuan Hukum Acara Pidana,” 2018, 19.
Praperadilan dimaksudkan sebagai sebuah mekanisme hukum pidana yang bisa ditempuh seseorang untuk melawan perlakuan atau keputusan yang dianggap sewenang-wenang. Tujuan dari pada praperadilan adalah untuk menegakkan hukum, keadilan, kebenaran melalui sarana pengawasan horizontal. ${ }^{20}$ Esensi dari praperadilan tidak lain untuk mengawasi tindakan upaya paksa yang dilakukan oleh penyidik atau penuntut umum terhadap tersangka, supaya tindakan itu benar-benar dilaksanakan sesuai dengan ketentuan undang-undang, benar-benar proporsional dengan ketentuan hukum, melindungi HAM bukan merupakan tindakan yang bertentangan dengan hukum dan HAM. ${ }^{21}$

Pembentukan mekanisme Praperadilan merupakan upaya dari pemerintah Indonesia untuk memperbaiki hukum acara pidana peninggalan Belanda yaitu Herzienne Inlands Reglement (H.I.R). Oleh karena dalam hukum acara pidana tersebut sering terjadi upaya paksa oleh aparat penegak hukum dilakukan tanpa menghormati hak asasi manusia, sehingga dibentuklah praperadilan dalam rangka mengawasi tindakan penyidik. $^{22}$ Dapat dipahami pula, bahwa intisari dari praperadilan adalah meletakkan hak dan kewajiban yang sama antara yang memeriksa dan yang diperiksa, serta menempatkan tersangka bukan sebagai objek yang diperiksa. Praperadilan juga berusaha menjamin asas accuasitor dalam hukum acara pidana yang notabene memandang seorang tersangka yang diperiksa bukan menjadi obyek tetapi

20 Deddi Diliyanto dan Zainal Asikin, "Perluasan Wewenang Praperadilan Pasca Putusan Mahkamah Konstitusi Nomor 21-PUU-XII-2014," Jurnal Ilmiah Hukum DE JURE: Kajian Ilmiah Hukum 3, no. 1 (2018): 30.

${ }^{21}$ Deddi Diliyanto dan Zainal Asikin, 30.

${ }^{22}$ Barkatullah, Praperadilan, 76. 
sebagai subyek menjamin, sehingga dapat dipahami bahwa adanya perlindungan hukum dan kepentingan HAM yang holistik bagi tersangka. ${ }^{23}$

Sebagai perbandingan, di negara yang sistem hukumnya menganut common law system seperti Amerika Serikat mengenal adanya Pre Trial Hearing, dan di Hong Kong mengenal Committal Proceeding. Pre Trial Hearing atau Preliminary Hearing suatu proses hukum antara penuntut umum dan penasihat hukum terdakwa dengan hakim yang dilakukan sebelum persidangan. $^{24}$ Penuntut umum berupaya meyakinkan hakim dengan menampilkan seluruh alat bukti agar kasus itu dapat dilimpahkan ke pengadilan. $^{\mathbf{2 5}}$ Sebaliknya, penasihat hukum berupaya menguji seluruh alat bukti yang ada termasuk latar belakang saksi sehingga dapat meyakinkan hakim bahwa kasus itu belum cukup bukti. ${ }^{26}$

Demi terlaksananya kepentingan pemeriksaan tindak pidana, undang-undang memberikan kewenangan kepada penyidik atau penuntut umum untuk melakukan tindakan upaya paksa seperti penangkapan, penahanan, penyitaan dan sebagainya. ${ }^{27}$ Dengan dasar tersebut, maka upaya paksa yang dilakukan pejabat penyidik atau penuntut umum terhadap tersangka, harus

${ }^{23}$ Muhamad Solichin dkk., "Politik Hukum Praperadilan Dalam Penegakan Hukum" (PhD Thesis, Universitas Muhammadiyah Surakarta, 2018), 16.

${ }^{24}$ Will Dobbie, Jacob Goldin, dan Crystal S. Yang, "The effects of pretrial detention on conviction, future crime, and employment: Evidence from randomly assigned judges," American Economic Review 108, no. 2 (2018): 12.

${ }^{25}$ Dobbie, Goldin, dan Yang, 13.

26 Platto, Pre-trial and pre-hearing procedures worldwide, 199.

27 Darwin Darwin, Dahlan Dahlan, dan Suhaimi Suhaimi, "Analisis Yuridis Putusan Praperadilan dalam Perspektif Sistem Peradilan Pidana," Jurnal Mercatoria 12, no. 1 (2019): 14. dipahami sebagai perlakuan yang dibenarkan undang-undang demi kepentingan pemeriksaan tindak pidana. ${ }^{28}$ Selain itu, tindakan paksa ini dibenarkan hukum dan undangundang yang pada akhirnya dapat merampas kemerdekaan dan kebebasan serta membatasi terhadap hak asasi tersangka. ${ }^{29}$ Dengan dasar tersebut, maka dalam hal pengujian terhadap tindakan paksa yang dianggap bertentangan dengan hukum, perlu diadakan suatu lembaga yang diberi wewenang untuk menentukan sah atau tidaknya tindakan paksa yang dilakukan penyidik atau penuntut umum. ${ }^{30}$ Dalam hal ini kewenangan tersebut dilimpahkan kepada praperadilan. Pasal 77 KUHAP merumuskan lebih jelas tentang ruang lingkup wewenang pengadilan negeri untuk memeriksa dan memutus praperadilan, yakni meliputi pemeriksaan terhadap sah atau tidaknya penangkapan, penahanan, penghentian penyidikan atau penghentian penuntutan serta ganti kerugian dan/atau rehabilitasi bagi seorang yang perkara pidananya dihentikan.

Secara rinci, sah atau tidaknya penangkapan, penahanan, penghentian penyidikan atau penghentian penuntutan diartikan sebagai hak tersangka untuk dapat mengajukan praperadilan apabila dalam proses penangkapan dan/atau penahanan, penyidik melanggar Pasal 21 KUHAP. Termasuk pelanggaran terhadap ketentuan

${ }^{28}$ Asep Suherman, "Penangkapan Sebagai Bentuk Upaya Paksa Penegakan Hukum Dalam Sistem Peradilan Pidana Di Indonesia," Supremasi Hukum: Jurnal Penelitian Hukum 29, no. 1 (2020): 11.

29 Komang Dara Trimarlina, I. Nyoman Sujana, dan Ida Ayu Putu Widiati, "Implementasi Perlindungan Hak Asasi Manusia Terhadap Pemeriksaan Dalam Proses Penyidikan," Jurnal Analogi Hukum 1, no. 3 (2019): 4.

${ }^{30}$ Masrur, "Kewenangan praperadilan dalam memutus sah tidaknya penetapan tersangka dikaitkan dengan prinsip Due Process of Law dalam sistem peradilan pidana Indonesia," 3. 
Pasal 24 KUHAP tentang penahanan terhadap tersangka melebihi batas waktu yang ditentukan. Sehingga dalam hal ini penyidik maupun penuntut umum berwenang menghentikan penyidikan atau penuntutan apabila hasil pemeriksaan penyidikan atau penuntutan tidak cukup bukti untuk diteruskan kepada pengadilan, ataupun apabila yang disangkakan terhadap tersangka bukan merupakan tindak pidana. ${ }^{31}$

Sementara, permintaan ganti kerugian dan/atau rehabilitasi bagi seorang yang perkara pidananya dihentikan pada tingkat penyidikan atau penuntutan juga dapat diajukan dalam praperadilan. Pasal 95 KUHAP menyebutkan bahwa tersangka ataupun keluarga tersangka, atau penasihat hukum tersangka dapat mengajukan tuntutan ganti kerugian dengan alasan penangkapan atau penahanan yang tidak sah. Termasuk apabila penggeledahan atau penyitaan yang bertentangan dengan ketentuan hukum dan undang-undang, serta terdapat kekeliruan mengenai orang yang sebenarnya mesti ditangkap, ditahan, atau diperiksa.

Kemudian, terkait dengan pemeriksaan permintaan rehabilitasi tuntutan ganti rugi yang diajukan kepada praperadilan, umumnya juga diikuti dengan permintaan rehabilitasi. Sebagaimana Pasal 1 angka 23 KUHAP menjelaskan rehabilitasi sebagai upaya pemulihan hak, kedudukan dan martabat seseorang apabila seseorang ditangkap, ditahan, dituntut, diadili tanpa alasan yang berdasarkan undang-undang atau karena kekeliruan mengenai orangnya atau penerapan hukumnya. Selanjutnya, Pasal 97 ayat (1) dan (2) KUHAP menyebutkan bahwa seseorang berhak memperoleh rehabilitasi apabila pengadilan memutuskan

31 Rambe, "Upaya Hukum Terhadap Praperadilan," 13. seseorang tersebut bebas atau lepas dari segala tuntutan hukum yang putusannya telah mempunyai kekuatan hukum yang tetap. Tujuan rehabilitasi sendiri dimaksudkan untuk mengembalikan dan membersihkan nama baik, harkat dan martabat tersangka atau terdakwa, serta keluarga atas tindakan aparat penegak hukum. ${ }^{32}$ Sehingga hak-hak tersangka dan keluarga dapat terlindungi.

Dalam mengajukan permohonan praperadilan tentang sah tidaknya tindakan dari aparat penegak hukum, harus memiliki alasan-alasan yang kuat. ${ }^{33}$ Pasal 79 KUHAP telah mengatur pihak-pihak yang berhak mengajukan permohonan kepada praperadilan. Mereka yang berhak mengajukan praperadilan di antaranya adalah tersangka, keluarga atau kuasa hukumnya. Lebih lanjut disebutkan bahwa tersangka, keluarga, atau kuasa hukumnya berhak mengajukan pemeriksaan tentang sah tidaknya penangkapan atau penahanan kepada Ketua Pengadilan Negeri. Di Pasal 79 KUHAP, disebutkan bahwa yang dapat diajukan kepada praperadilan hanyalah masalah penangkapan dan penahanan, sedangkan upaya lain seperti penggeledahan dan penyitaan tidak disebutkan secara langsung.

Tersangka, ahli warisnya, dan kuasa hukumnya, sesuai dengan Pasal 95 ayat (2) KUHAP juga dapat menuntut ganti kerugian atas penangkapan atau penahanan serta tindakan lain tanpa alasan yang berdasarkan undang-undang atau karena kekeliruan mengenai orang atau hukum yang diterap-

\footnotetext{
${ }^{32}$ Dimas Tiga Saputra, "Ganti Kerugian Dan Rehabilitasi Dalam Perkara Pidana" (PhD Thesis, Skripsi, Universitas Muhammadiyah Magelang, 2017), 15.

33 Wahyu Iswantoro, "Penemuan Hukum Oleh Hakim Dan Implikasi Terhadap Perkembangan Praperadilan," Jurnal Hukum dan Bisnis (Selisik) 4, no. 1 (2018): 17.
} 
kan. Termasuk pihak-pihak yang berkepentingan dalam hal ini juga dapat mengajukan tuntutan ganti rugi, sebagaimana telah dijelaskan dalam Pasal 81 KUHAP. $^{34}$

Selain tersangka, keluarganya, ahli warisnya, dan kuasa hukumnya, penuntut umum atau pihak ketiga yang berkepentingan juga memiliki hak untuk mengajukan praperadilan. ${ }^{35}$ Seperti dijelaskan di dalam Pasal 80 KUHAP bahwa permintaan untuk memeriksa sah atau tidaknya suatu penghentian penyidikan atau penuntutan dapat diajukan oleh penyidik atau penuntut umum atau pihak ketiga yang berkepentingan kepada ketua pengadilan negeri dengan menyebutkan alasannya. Sehingga apabila dalam suatu perkara pidana, seorang penyidik menghentikan penyidikan tanpa alasan yang dibenarkan oleh undang-undang, maka penuntut umum dan pihak ketika yang berkepentingan berhak melaporkan kepada praperadilan. $^{\mathbf{3 6}}$

Dalam perkembangannya, MK melalui Putusan Nomor 21/PUU-XII/2014 secara tidak langsung telah mengubah rumusan ruang lingkup praperadilan dalam KUHAP, sehingga hal ini juga menimbulkan dampak kepada sistem hukum acara pidana Indonesia. ${ }^{37}$ Putusan MK Nomor 21/PUUXII/2014 telah memperluas ruang lingkup praperadilan yang awalnya hanya memeriksa sah tidaknya penangkapan, penahanan, penghentian penyidikan atau penghentian penuntutan, tuntutan ganti rugi dan rehabilitasi, menambahkan satu ruang lingkup baru, terkait penetapan seorang tersangka.

${ }^{34}$ Harahap, "Pembahasan Permasalahan dan Penerapan KUHAP Jilid I,” 13.

${ }^{35}$ Harahap, 14.

${ }^{36}$ Harahap, 15.

37 Darwin, Dahlan, dan Suhaimi, "Analisis Yuridis Putusan Praperadilan dalam Perspektif Sistem Peradilan Pidana," 2019, 73.
Dalam putusannya, MK menyatakan inkonstitusional bersyarat (conditionally inconstitutional) terhadap frasa "bukti permulaan", "bukti permulaan yang cukup", dan "bukti yang cukup" di dalam Pasal 1 angka 14, Pasal 17, dan Pasal 21 ayat (1) KUHAP sepanjang dimaknai minimal dua alat bukti sesuai Pasal 184 KUHAP. Pasal 77 huruf a KUHAP dinyatakan inkonstitusional bersyarat, sepanjang tidak dimaknai termasuk penetapan tersangka, penggeledahan, dan penyitaan. Maksud dari penetapan tersangka dalam hal ini adalah apa yang dimaksud di dalam Pasal 1 angka 14 KUHAP yakni seseorang dikatakan sebagai tersangka apabila seorang tersebut yang karena perbuatannya atau keadaannya, berdasarkan bukti permulaan patut diduga sebagai pelaku tindak pidana.

Mahkamah berpendapat, bahwa meski dibatasi secara limitatif dalam Pasal 1 angka 10 juncto Pasal 77 huruf a KUHAP, namun penetapan tersangka adalah bagian dari proses penyidikan yang memiliki kemungkinan terjadinya tindakan sewenangwenang oleh penyidik. $^{38}$ Dengan dasar tersebut, maka dapat dilihat, bahwa diperlukan penegasan terkait penetapan tersangka yang notabene merupakan bagian dari proses penyidikan yang dapat dimintakan perlindungan melalui praperadilan. Puncaknya, hal ini membuat MK menghapus keberadaan Pasal 83 ayat (2) KUHAP.

Dalam ratio decedendi putusan Nomor 21/PUU-XII/2014, MK menyebutkan bahwa sistem praperadilan merupakan salah satu mekanisme kontrol terhadap

38 Jully Constantia Sambow, "Bukti Permulaan Menurut Kitab Undang-Undang Hukum Acara Pidana Dalam Pengaruhnya Terhadap Perkapolri Nomor 14 Tahun 2012 Tentang Manajemen Penyidikan Tindak Pidana," LEX CRIMEN 7, no. 7 (2018): 12. 
kemungkinan tindakan sewenang-wenang oleh penyidik atau penuntut umum dalam melakukan penangkapan, penggeledahan, penyitaan, penyidikan, penuntutan, penghentian penyidikan dan penghentian penuntutan. Dengan ditetapkannya seseorang sebagai tersangka, hal ini berarti bahwa sejak penetapan itu, seseorang tersebut terbatasi beberapa hak-hak asasinya. Dengan dasar tersebut, maka diperlukan adanya perlindungan dengan dimasukkannya penetapan tersangka ke dalam ruang lingkup praperadilan. Hal ini menjadi tepat, sebab tindakan penegak hukum dalam menentukan status tersangka tidak dapat dilakukan semena-mena. ${ }^{39}$ Lebih lanjut, apabila terjadi pelanggaran prosedur, ataupun penetapan tersangka dilakukan tanpa didasarkan sekurang-kurangnya dua alat bukti, maka tindakan tersebut dapat diuji praperadilan. ${ }^{40}$

Terkait alasan-alasan penetapan tersangka yang dapat diajukan praperadilan, di antaranya, seperti ketika penetapan tersangka tidak sah apabila pemeriksaan saksi-saksi, ahli, tersangka, penggeledahan, serta penyitaan dilakukan setelah penetapan tersangka sehingga tidak terpenuhinya dua alat bukti. ${ }^{41}$ Selain itu, permohonan praperadilan yang kedua kalinya mengenai penetapan tersangka tidak dapat dikategorikan sebagai ne bis in idem, karena belum

39 Tristam P. Moeliono, “Asas Legalitas dalam Hukum Acara Pidana: Kritikan terhadap Putusan MK tentang Praperadilan," Jurnal Hukum Ius Quia Iustum 22, no. 4 (2015): 17.

40 Hamzah, "Penjelasan Hukum (Restatement) tentang Bukti Permulaan Yang Cukup," 47.

41 Deddi Diliyanto dan Zainal Asikin, "Perluasan Wewenang Praperadilan Pasca Putusan Mahkamah Konstitusi Nomor 21-PUU-XII-2014," Jurnal Ilmiah Hukum DE JURE: Kajian Ilmiah Hukum 3, no. 1 (2018): 11. menyangkut pokok perkara. ${ }^{\mathbf{4 2}}$ Termasuk, dalam hal penetapan tersangka atas dasar hasil pengembangan penyidikan terhadap tersangka lainnya dalam berkas berbeda juga akan dianggap tidak sah. ${ }^{43}$

Puncaknya, dalam maksud menjamin adanya kepastian hukum di dalam praperadilan, Pasal 2 Ayat (2) Perma No.4/2016 kemudian membatasi bahwa pemeriksaan praperadilan terbatas pada sah atau tidaknya penetapan tersangka dan hanya menyangkut aspek formil saja. Lebih lanjut, Perma No.4/2016 ini juga membatasi bahwa praperadilan hanya dapat menilai apakah dalam penetapan tersangka tersebut telah terdapat paling sedikit dua alat bukti yang sah atau tidak, serta objek praperadilan tidak memasuki materi perkara.

\section{Polemik penggunaan daluwarsa sebagai dasar pengajuan permohonan prapera- dilan di indonesia}

Di dalam Perma No. 4/2016, diatur, bahwa praperadilan hanya terbatas dalam memeriksa dalam aspek formil, sehingga tidak diperkenankan masuk pokok perkara. Akan tetapi, tidak ada penjelasan lebih lanjut terkait dengan hal tersebut. Hal ini menyebabkan tidak ada kategorisasi yang jelas terkait dengan "aspek formil yang notabene tidak masuk ke pokok perkara." Hal ini menyebabkan lahirnya perdebatan dalam praktiknya terkait dengan alasan apa yang masuk aspek formil atau materiil. Salah satunya adalah terkait dengan daluwarsa.

Pendapat pertama, mengatakan bahwa daluwarsa merupakan aspek materiil. Pendapat ini didasarkan pada anggapan, bahwa pengaturan daluwarsa tidak diatur di dalam KUHAP yang bersifat

${ }^{42}$ Moeliono, “Asas Legalitas dalam Hukum Acara Pidana,” 19.

${ }^{43}$ Moeliono, 20. 


\section{Volksgeist}

Vol. 3 No. 2 Desember 2020

DOI 10.24090/volksgeist.v3i2.4125

formil dan prosedural. ${ }^{44}$ Melainkan terletak di dalam KUHP, yang mana pengaturannya bersifat materiil. ${ }^{45}$ Sehingga pendapat ini memiliki keyakinan bahwa ruang lingkup pengaturan daluwarsa adalah ruang lingkup yang bersifat materiil. Artinya, pengujian terhadap daluwarsa di dalam praperadilan telah masuk ke dalam ranah pokok perkara. Selain itu, esensi pengaturan daluwarsa juga menunjukkan jenis-jenis tindak pidana yang sudah ditentukan jangka waktu pemidanaannya, sehingga menguji daluwarsa --menurut logika hukum pidana yang berlaku - sama dengan mempersoalkan mengenai tindak pidana itu sendiri. ${ }^{46}$

Esensi pengaturan di dalam Perma No.4/2016 yang notabene juga senada dengan Putusan MK No.21/PUU-XII/2014, maka dapat dipahami, bahwa ruang lingkup utama pengaturan Perma No.4/2016 bersifat formil dan prosedural. Hal ini berarti, melingkupi kuasa praperadilan atas permasalahan penetapan tersangka yang mewajibkan dipenuhinya dua alat bukti. ${ }^{47}$ Termasuk penilaian terhadap telah dipanggilnya secara patut sebagai saksi sebelum penetapan dirinya sebagai tersangka. Sehingga secara yuridis disimpulkan, bahwa persoalan daluwarsa bukan merupakan lingkup kewenangan praperadilan.

Pendapat kedua, mengatakan bahwa daluwarsa merupakan aspek

\footnotetext{
${ }^{44}$ Barda Nawawi Arief, Masalah penegakan hukum dan kebijakan hukum pidana dalam penanggulangan kejahatan (Prenada Media, 2018), 77.

${ }^{45}$ Barda Nawawi Arief, 78.

${ }^{46}$ Fani Patriansyah, "Prosedur Penghentian Penuntutan Hak Menuntut Hukum Dalam Perkara Pidana" (PhD Thesis, Universitas Muhammadiyah Palembang, 2019), 17.

${ }^{47}$ Hal ini juga selaras dengan Putusan MK No.21/PUU-XII/2014 yang pada intinya penambahan penetapan tersangka sebagai objek praperadilan dibatasi terhadap telah terpenuhi atau tidaknya dua alat bukti.
}

formil. Pendapat ini didasarkan pandangan, bahwa daluwarsa belum masuk ke pokok perkara, karena hanya melihat suatu perkara secara administratif. Dengan adanya putusan MK yang memperluas ruang lingkup praperadilan, maka alasan permohonan praperadilan terkait tidak sahnya penetapan tersangka, maka dapat menggunakan logika a contrario dari alasan permohonan praperadilan terkait tidak sahnya SP 3. Penjelasan alasan dengan logika a contrario ini diuraikan sebagai berikut ini

Skema 1. Skema Logika Alasan Pengajuan Praperadilan

\section{Jika}

Alasan yang mungkin diajukan dalam praperadilan

dengan alasan tidak sahnya SP 3 adalah:

1. Terdapat bukti yang cukup dalam penyidikan untuk membuktikan perbuatan dan kesalahan tersangka.

2. Peristiwa yang disangkakan adalah tindak pidana.

3. SP 3 tidak didasarkan pada penghentian demi hukum karena hapusnya kewenangan menuntut. Tidak Ne Bis in Idem Belum Meninggal Dunia Belum Daluwarsa

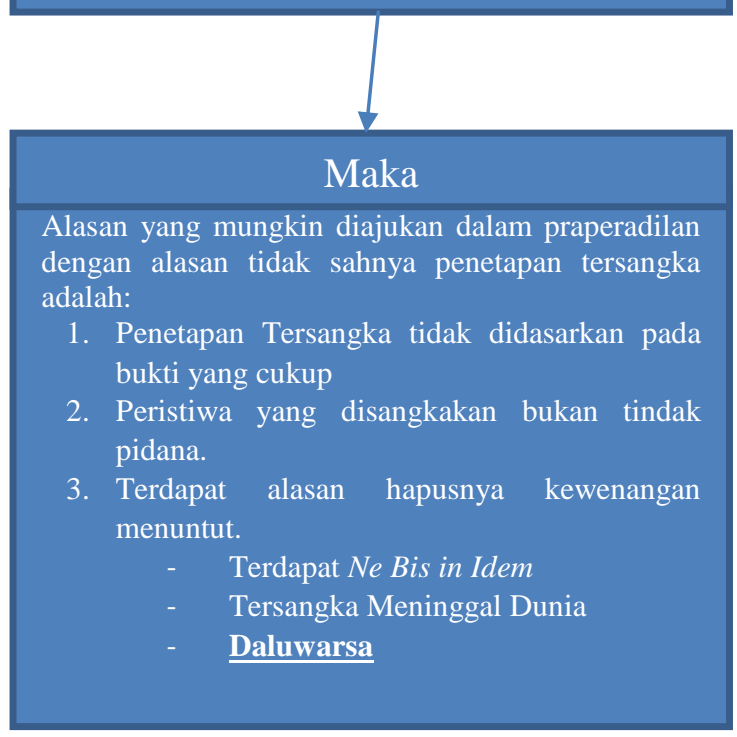

Berdasarkan penjelasan di atas, kemungkinan alasan praperadilan tersebut di atas, maka penggunaan daluwarsa secara yuridis sangat mungkin dijadikan dan 
diajukan sebagai dasar permohonan praperadilan, baik itu untuk membantah tidak adanya daluwarsa dalam kerangka alasan tidak sahnya SP 3 maupun untuk membuktikan benar adanya daluwarsa dalam kerangka alasan tidak sahnya penetapan tersangka. Pada praktiknya, terbukti alasan ini digunakan dalam Putusan Praperadilan sehingga mengabulkan permohonan praperadilan yang beralasan daluwarsa, seperti pada Putusan Praperadilan Nomor: 143/Pid.Prap/2016/PN.Jkt.Sel. Dalam kasus ini, Irsanto Ongko (Pemohon) ditetapkan sebagai Tersangka setelah melalui hasil Penyidikan yang meliputi pemeriksaan terhadap para saksi, ahli dan didukung oleh barang bukti berupa dokumen. Kemudian pada 13 Oktober 2015 Badan Reserse Kriminal Polri (Termohon), secara meyakinkan menetapkan Pemohon sebagai tersangka tindak pidana kesaksian dan keterangan palsu, setelah terpenuhi lebih dari dua alat bukti yaitu keterangan saksi, ahli, surat dan persesuaian antara keterangan saksi, ahli dan surat.

Terhadap penetapan tersangka ini, melalui Pengadilan Negeri Jakarta Selatan, Pemohon mengajukan permohonan praperadilan yang pada pokoknya meminta hakim untuk menyatakan tindakan Termohon yang menetapkan Pemohon sebagai Tersangka berdasarkan Laporan Polisi Nomor: LP/1064/IX/2015/Bareskrim tanggal 10 September 2015 adalah tidak sah, sebab tindak pidana yang disangkakan kepada pemohon telah kedaluwarsa.

Dalam pertimbangan hukumnya, hakim menyatakan bahwa tindak pidana kesaksian palsu yang telah dilaporkan oleh Pelapor (Doly Sagita Hutagalung) pada tanggal 10 September 2015 dengan surat laporan polisi Nomor: LP/1064/IX/ 2015/ Bareskrim, tertanggal 10 September 2015 telah lewat tenggang waktu untuk memproses perkara ini. Kemudian hakim menyatakan bahwa waktu Penetapan Pemohon sebagai Tersangka telah melampaui waktu/Daluwarsa, sebagaimana hal ini bertentangan dengan Pasal 76 huruf c 2 Peraturan Kapolri Nomor 14 Tahun 2012 mengenai Demi Hukum perkara telah daluwarsa. ${ }^{48}$ Sehingga penetapan pemohon sebagai tersangka yang dilakukan oleh Termohon tidak mempunyai kekuatan hukum.

Kemudian hakim dalam putusannya Nomor: 143/Pid.Prap/ 2016/PN.Jkt.Sel tanggal 29 November 2016 menjatuhkan putusan untuk mengabulkan permohonan praperadilan dan menyatakan bahwa proses penyidikan dan penetapan tersangka yang dilakukan oleh termohon adalah tidak sah dan tidak berdasar hukum. Hakim kemudian memerintahkan Termohon untuk menghentikan penyidikan terhadap Pemohon dan menerbitkan Surat Penghentian Proses Penyidikan (SP3), termasuk menyatakan tidak sah segala keputusan atau penetapan yang dikeluarkan lebih lanjut oleh Termohon yang berkaitan dengan Penetapan Tersangka terhadap diri Pemohon oleh Termohon.

Dalam putusan ini dapat kita lihat bahwa hakim telah melakukan penilaian terhadap penetapan tersangka dengan menganggap daluwarsa sebagai bagian dari aspek formil. Hakim dalam putusannya juga telah membahas mengenai daluwarsa yang diatur di dalam Pasal 79 KUHP. Sehingga, berdasarkan putusan hakim yang berkekuatan hukum tetap ini (inkracht van

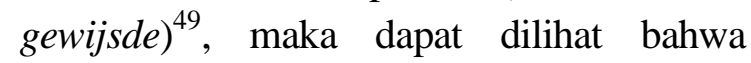

${ }^{48}$ Pada saat itu aturan yang dipakai masih Perkap 14/2012, karena pada saat itu belum terbit Perkap 6/2019

${ }^{49}$ Pada putusan praperadilan tidak ada upaya hukum yang dapat dilakukan, sehingga putusan 


\section{Volksgeist}

Vol. 3 No. 2 Desember 2020

DOI 10.24090/volksgeist.v3i2.4125

daluwarsa digolongkan dalam aspek formil suatu perkara, sehingga dapat digunakan sebagai alasan praperadilan.

Putusan MK No. 21/PUU-XII/2014 yang telah menambahkan sah atau tidaknya penetapan tersangka menjadi bagian dari ruang lingkup objek praperadilan juga memiliki batasan-batasan. MK memberikan batasan bahwa penilaian sah atau tidaknya penetapan tersangka hanya khusus mengenai terpenuhi atau tidaknya dua alat bukti yang sah dalam penetapan tersangka tersebut. Dengan demikian Putusan Praperadilan Nomor: 143/Pid.Prap/2016 PN.Jkt.Sel juga telah bertentangan dengan maksud penetapan tersangka di dalam Putusan MK No. 21/PUU-XII/2014. Hal ini disebabkan bahwa Putusan Praperadilan Nomor: 143/Pid.Prap/2016 PN.Jkt.Sel telah melakukan penilaian tentang objek praperadilan penetapan tersangka dengan pertimbangan daluwarsa, bukan khusus mengenai terpenuhinya dua alat bukti.

Di sisi lain, dalam hukum positif Indonesia, tidak terdapat penjelasan maupun batasan yang jelas dan tertulis terkait ruang lingkup atau hal-hal yang disebut sebagai aspek formil dan materiil. ${ }^{50}$ Lebih lanjut, apa yang diatur di dalam KUHP tidak dapat dianggap selalu mengenai aspek materiil. Daluwarsa juga merupakan salah satu acuan menakar tempus delicti atau waktu suatu delik atau tindak pidana. ${ }^{51}$ Daluwarsa merupakan salah satu titik tolok bagaimana

tersebut otomatis berkekuatan hukum tetap (inkracht van gewijsde). Selanjutnya lihat Lovelia Gamelia Kimbal, "Tinjauan Yuridis Pelaksanaan Putusan Akibat Praperadilan Yang Diterima," Lex Et Societas 2, no. 6 (2014): 62.

${ }^{50}$ Khasan Asari "Analisa Putusan Hakim dalam Aspek Formil dan Materiil Terhadap Putusan Nomor451/PID-SUS/2012/PN SLMN," 2013, 12.

${ }^{51}$ Fajlurrahman Jurdi, Logika Hukum: Edisi Pertama (Prenada Media, 2019), 179. sebuah delik pidana -- secara administratif dapat dilanjutkan kepada tingkat penuntutan. ${ }^{52}$ Sehingga apabila dalam menemukan dua alat bukti, penyidik menemukan bahwa tindak pidana yang dilakukan seseorang telah kedaluwarsa -- sebagaimana kedaluwarsa merupakan hal yang diatur di dalam KUHP -- maka penyidik dapat menghentikan proses penyidikan.

Jika kita membandingkan ruang lingkup objek praperadilan dengan alasanalasan yang dapat menghentikannya proses penyidikan, maka pada kasus daluwarsa sebuah tindak pidana pidana --secara formil- seharusnya dapat dijadikan sebagai dasar permohonan praperadilan. Dalam hal ini, jika hasil pemeriksaan penyidikan atau penuntutan tidak memiliki cukup bukti untuk meneruskan perkaranya ke sidang pengadilan, atau apa yang disangkakan kepada tersangka bukan merupakan tindak pidana, maka tidaklah mungkin untuk diteruskan ke sidang pengadilan. ${ }^{\mathbf{5 3}}$ Sementara, penghentian proses penyidikan atau penuntutan dilakukan penyidik atau penuntut umum tersebut dapat terjadi karena alasan Nebis In Idem ataupun jika apa yang disangkakan kepada tersangka terdapat unsur daluwarsa untuk menuntut. ${ }^{54}$ Oleh karena itu, apabila dalam pemeriksaan penyidikan atau penuntutan dijumpai unsur kedaluwarsa dalam perkara yang sedang diperiksa, maka wajar penyidikan atau penuntutan dihentikan.

Sebagaimana hal-hal yang menjadi alasan penghentian penyidikan tersebut diatur di dalam Pasal 109 ayat (2) KUHAP. Di antaranya, pertama, apabila suatu peris-

52 Rudy Antow, "Hapusnya Kewenangan Menuntut Pidana Pembunuhan Karena Daluwarsa," LEX CRIMEN 8, no. 12 (2019): 8.

${ }^{53}$ Harahap, "Pembahasan Permasalahan dan Penerapan KUHAP Jilid I,” 15.

${ }^{54}$ Harahap, 21. 
tiwa yang disangkakan tidak diperoleh bukti yang cukup. Hal ini dapat terjadi apabila penyidik tidak memperoleh cukup bukti untuk menuntut tersangka atau bukti yang diperoleh penyidik tidak memadai untuk membuktikan kesalahan tersangka. Kedua, peristiwa yang disangkakan bukan merupakan tindak pidana. Ketiga, penghentian penyidikan dapat dilakukan demi hukum. Alasan 'demi hukum' ini dapat dipakai apabila terdapat alasan-alasan hapusnya hak menuntut dan hilangnya hak menjalankan pidana. Bagir Manan menjelaskan bahwa maksud penyidikan dihentikan 'demi hukum' pada pokoknya sesuai dengan alasan hapusnya hak menuntut dan hilangnya kewajiban menjalankan pidana. Antara lain, perkara delik aduan telah dicabut pengaduannya (Pasal 15 KUHP), Ne Bis In Idem (Pasal 76 KUHP), tersangka meninggal dunia (Pasal 77 KUHP), atau perkara tersebut telah kedaluwarsa (Pasal 78 KUHP). ${ }^{55}$

Pasal 76 ayat (1) Peraturan Kepala Kepolisian Negara Republik Indonesia Nomor 14 Tahun 2012 tentang Manajemen Penyidikan Tindak Pidana (Perkap 14/2012), juga menyatakan bahwa penghentian penyidikan dapat dilakukan apabila tidak terdapat cukup bukti; peristiwa tersebut bukan merupakan tindak pidana dan; demi hukum, karena: tersangka meninggal dunia; perkara telah kedalwuarsa; pengaduan dicabut (khusus delik aduan); serta tindak pidana tersebut telah memperoleh putusan hakim yang mempunyai kekuatan hukum tetap (nebis in idem). Hal ini juga sejalan dengan Pasal 11 ayat (1) Peraturan Kepala Badan Reserse Kriminal Kepolisian Negara

55 Daniel Ch M. Tampoli, "Penghentian Penuntutan Perkara Pidana Oleh Jaksa Berdasarkan Hukum Acara Pidana," Lex Privatum 4, no. 2 (2016): 4.
Republik Indonesia tentang Standar Operasional Prosedur Pelaksanaan Tindak Pidana Nomor 3 tahun 2014 (Perkaba 3/2014) yang menjelaskan bahwa penyidikan dapat dihentikan apabila tidak terdapat cukup bukti, bukan tindak pidana, demi hukum (daluwarsa, nebis in idem, tersangka meninggal dunia, maupun jika pengaduan dicabut (dalam kasus delik aduan)).

Apabila kita berpedoman pada logika formil dan materiil hukum pidana, ketika sebuah peristiwa yang disangkakan merupakan nebis in idem, tersangka meninggal dunia, pengaduan dicabut (dalam kasus delik aduan), termasuk kedaluwarsa, maka keempat hal ini seharusnya termasuk aspek formil pidana dan dapat dijadikan dasar permohonan praperadilan. Logika ini didasarkan pada hak dan wewenang penghentian proses penyidikan dan penuntutan -yang merupakan aspek formil pidana -dapat dilakukan apabila tindak pidana telah pernah dituntut dan diadili, dan putusan sudah memperoleh kekuatan hukum tetap (nebis in idem), atau disebabkan perkara disangkakan terdapat unsur kedaluwarsa untuk menuntut. ${ }^{56}$

Puncaknya, apabila melihat praperadilan dalam perspektif ius constituendum dengan memperhatikan perlindungan HAM serta kepastian hukum, terdapat kemungkinan jika nantinya daluwarsa secara yuridis dan tertulis dapat dijadikan dasar permohonan praperadilan.

Perbandingan pendapat yang menyatakan bahwa daluwarsa merupakan aspek formil atau aspek materiil dapat disimpulkan di dalam tabel berikut:

${ }^{56}$ Harahap, "Pembahasan Permasalahan dan Penerapan KUHAP Jilid I,” 5-6. 


\section{Volksgeist}

Vol. 3 No. 2 Desember 2020

DOI 10.24090/volksgeist.v3i2.4125

Tabel 1. Analisis Perbandingan Daluwarsa sebagai Aspek Formil dan Materiil

\begin{tabular}{l} 
Daluwarsa sebagai \\
Aspek Formil \\
\hline Daluwarsa merupakan \\
aspek materiil, sebab \\
pengaturan daluwarsa \\
tidak diatur dalam \\
KUHAP yang bersifat \\
formil dan prosedural. \\
Melainkan di dalam \\
KUHP, yang pengatu- \\
rannya bersifat materiil. \\
Pengujian terhadap \\
daluwarsa di dalam pra- \\
peradilan telah masuk \\
ke dalam ranah pokok \\
perkara.
\end{tabular}

Daluwarsa sebaga Aspek Materiil

Tidak terdapat penjelasan maupun batasan yang jelas dan tertulis terkait ruang lingkup atau hal-hal yang disebut sebagai aspek formil dan materiil.

Apa yang diatur di dalam KUHP tidak dapat dianggap selalu mengenai aspek materiil. Kedaluwarsa juga merupakan salah satu acuan menakar tempus delicti atau waktu suatu delik atau tindak pidana, Apabila dalam menemukan dua alat bukti, penyidik menemukan bahwa tindak pidana yang dilakukan seseorang telah kedaluwarsa sebagaimana kedaluwarsa merupakan hal yang diatur di dalam KUHP maka penyidik dapat menghentikan proses penyidikan.

Esensi pengaturan daluwarsa juga menunjukkan jenis-jenis tindak pidana yang sudah ditentukan jangka wak tu pemidanaannya, sehingga menguji daluwarsa sama dengan mem persoalkan mengenai tindak pidana itu sendiri.
Jika membandingkan ruang lingkup objek praperadilan dengan alasan-alasan yang dapat menghentikannya proses penyidikan, maka pada kasus daluwarsa tindak pidana secara formil seharusnya dapat dijadikan sebagai dasar permohonan praperadilan. Dalam hal ini, jika hasil pemeriksaan penyidikan atau penuntutan tidak memiliki cukup bukti untuk meneruskan perkaranya ke sidang pengadilan, atau apa yang disangkakan kepada tersangka bukan merupakan tindak pidana, maka tidaklah mungkin untuk diteruskan ke sidang pengadilan. Sehingga, seharusnya kedaluwarsa dapat dijadikan objek praperadilan, sebab berkaitan erat dengan proses penetapan seorang tersangka.

Perma No.4/2016 menyatakan bahwa objek praperadilan bersifat formil dan prosedural, yang hanya melingkupi kuasa praperadilan atas permasalahan penetapan tersangka yang mewajibkan dipenuhinya dua alat bukti.

Pasal 109 ayat (2)

KUHAP, Pasal 76 ayat (1) Perkap 14/2012, dan Pasal 11 ayat (1) Perkaba 3/2014 mengatur hal-hal yang dapat menjadi alasan penghentian penyidikan. Di antaranya, pertama, apabila suatu peristiwa yang disangkakan tidak diperoleh bukti yang cukup. Hal ini dapat terjadi apabila penyidik tidak memperoleh cukup bukti untuk menuntut tersangka atau bukti yang diperoleh penyidik tidak memadai untuk membuktikan kesalahan tersangka. Kedua, peristiwa yang disangkakan bukan merupakan tindak pidana. Ketiga, penghentian penyidikan dapat dilakukan demi hukum. Alasan 'demi hukum' ini dapat dipakai apabila terdapat alasanalasan hapusnya hak menuntut dan hilangnya hak menjalankan pidana. Alasan 'demi hukum' pada pokoknya sesuai dengan alasan hapusnya hak menuntut dan hilangnya kewajiban menjalankan pidana. Alasan 'demi hukum' Antara lain, perkara delik aduan telah dicabut pengaduannya (Pasal 15 KUHP), Ne Bis In Idem (Pasal 76 KUHP), tersangka meninggal dunia (Pa- 
sal 77 KUHP), atau perkara tersebut telah kadaluwarsa (Pasal 78 KUHP. Sehingga, keempat hal tersebut seharusnya dapat dikategorikan sebagai aspek formil, dan dapat diajukan sebagai objek praperadilan.

Perkembangan ruang lingkup praperadilan yang semakin meluas. Fakta ini terlihat dari banyaknya putusanputusan praperadilan yang mengabulkan di luar daripada objek yang ditentukan di dalam KUHAP dengan alasan bahwa proses penetapan tersangka, maupun proses prosedural lainnya yang dilakukan oleh penyidik melanggar hak asasi tersangka.

\section{PENUTUP}

Pada awalnya di KUHAP berdasarkan Pasal 1 angka 10 jo. Pasal 77, maka dapat dipahami bahwa alasan praperadilan hanyalah limitatif terkait sah atau tidaknya penangkapan, penahanan, penghentian penyidikan atau penghentian Penuntutan, ganti kerugian, dan atau rehabilitasi bagi seorang yang perkara pidananya dihentikan pada tingkat penyidikan atau penuntutan. Dalam perkembangannya, pasca Putusan MK No. 21/PUU-XII/2014, alasan praperadilan ditambahkan dengan penggeledahan, penyitaan, dan penetapan tersangka. Terkait dengan penetapan tersangka tersebut juga ditegaskan dalam Pasal 2 ayat (2) Perma No. 4/2016 yang menyebutkan bahwa pemeriksaan penetapan tersangka hanya memeriksa terkait dengan formil semata. Pada praktiknya, karena tidak ada kategorisasi yang jelas terkait dengan aspek formil, maka menimbulkan dilematika. Salah satunya terkait dengan daluwarsa yang menjadi polemik terkait dengan pengelompokannya yang termasuk aspek formil atau materiil. Dalam perkembangannya, daluwarsa mulai diakui sebagai alasan formil yang notabene tidak menyentuh pokok perkara, sehingga dapat digunakan sebagai alasan praperadilan.

\section{DAFTAR PUSTAKA}

Antow, Rudy. "Hapusnya Kewenangan Menuntut Pidana Pembunuhan karena Daluwarsa." LEX CRIMEN 8, no. 12 (2019).

Barda Nawawi Arief, S. H. Masalah penegakan hukum dan kebijakan hukum pidana dalam penanggulangan kejahatan. Prenada Media, 2018.

Barkatullah, Abdul Halim. Praperadilan: Sarana Perlindungan Tersangka dalam Sistem Peradilan Pidana Indonesia (sesudah diedit editor). Nusa Media, 2020.

Darwin, Darwin, Dahlan Dahlan, dan Suhaimi Suhaimi. "Analisis Yuridis Putusan Praperadilan dalam Perspektif Sistem Peradilan Pidana." Jurnal Mercatoria 12, no. 1 (2019): 68-79.

"Analisis Yuridis Putusan Praperadilan dalam Perspektif Sistem Peradilan Pidana." Jurnal Mercatoria 12, no. 1 (2019): 68-79.

Deddi Diliyanto, S. H., dan S. H. Zainal Asikin. "Perluasan Wewenang PRaperadilan Pasca Putusan Mahkamah Konstitusi Nomor 21PUU-XII-2014." Jurnal Ilmiah Hukum DE JURE: Kajian Ilmiah Hukum 3, no. 1 (2018): 28-55. 
Dobbie, Will, Jacob Goldin, dan Crystal S. Yang. "The effects of pretrial detention on conviction, future crime, and employment: Evidence from randomly assigned judges." American Economic Review 108, no. 2 (2018): 201-40.

Gultom, Saddam Setia, dan R. B. Sularto. "Ide Dasar Keseimbangan Dalam Penetapan Status Tersangka Sebagai Objek Praperadilan Oleh Kekuasaan Kehakiman Di Indonesia." Law Reform 12, no. 1 (2016): 101-120.

Hamzah, Chandra M. "Penjelasan Hukum (Restatement) tentang Bukti Permulaan Yang Cukup," 2014.

Hiariej, Eddy OS. Prinsip-prinsip hukum pidana. Cahaya Atma Pustaka, 2016. Iswantoro, Wahyu. "Penemuan Hukum Oleh Hakim Dan Implikasi Terhadap Perkembangan Praperadilan.” Jurnal Hukum dan Bisnis (Selisik) 4, no. 1 (2018): 43-53.

Jurdi, Fajlurrahman. Logika Hukum: Edisi Pertama. Prenada Media, 2019.

Kalo, Syafruddin, dan M. Hamdan. "Perluasan Kewenangan Praperadilan Terkait Hak-hak Tersangka dalam Konteks Pembaharuan Hukum Acara Pidana," 2018.

Kusuma, I. Made Wisnu Wijaya, dan $\mathrm{Ni}$ Made Sukaryati Karma. "Upaya Hukum Praperadilan dalam Sistem Peradilan Pidana di Indonesia." Jurnal Interpretasi Hukum 1, no. 2 (2020): 73-77.

Kusumastuti, Ely. "Penetapan Tersangka Sebagai Obyek Praperadilan." Yuridika 33, no. 1 (2018): 1-18.

Masrur, Fikri Akbar Hadithna. "Kewenangan praperadilan dalam memutus sah tidaknya penetapan tersangka dikaitkan dengan prinsip Due Process of Law dalam sistem peradilan pidana Indonesia," 2019.

Moeliono, Tristam P. “Asas Legalitas dalam Hukum Acara Pidana: Kritikan terhadap Putusan MK tentang Praperadilan." Jurnal Hukum Ius Quia Iustum 22, no. 4 (2015): 594616.

Moningka, Paul Eliezer Tuama. "Praperadilan sebagai Mekanisme Kontrol terhadap Tindakan Penyidik dalam Menetapkan Tersangka Menurut Putusan Mk Nomor: 21/puu-xii/2014." Lex Crimen 6, no. 6 (2017).

Muladi dan Dwidja Priyanto. PertanggungJawaban Pidana Korporasi. Bandung: Kencana, 2010. PATRIANSYAH, FANI. "Prosedur Penghentian Penuntutan Hak Menuntut Hukum Dalam Perkara Pidana." PhD Thesis, Universitas Muhammadiyah Palembang, 2019.

Rambe, M. Irfan Islami. "UPAYA HUKUM TERHADAP PRAPERADILAN." JURNAL PIONIR 2, no. 3 (2017).

Sambow, Jully Constantia. "BUKTI PERMULAAN MENURUT KITAB UNDANG-UNDANG HUKUM ACARA PIDANA DALAM PENGARUHNYA TERHADAP PERKAPOLRI NOMOR 14 TAHUN 2012 TENTANG MANAJEMEN PENYIDIKAN TINDAK PIDANA." LEX CRIMEN 7, no. 7 (2018).

Saputra, Dimas Tiga. "GANTI KERUGIAN DAN REHABILITASI DALAM PERKARA PIDANA." PhD Thesis, Skripsi, Universitas Muhammadiyah Magelang, 2017. 
SOLICHIN, MUHAMAD, S. H. Absori, S.

H. Wardah Yuspin, dan M. Kn. "Politik Hukum Praperadilan Dalam Penegakan Hukum.” PhD Thesis, Universitas Muhammadiyah Surakarta, 2018.

Suherman, Asep. "Penangkapan Sebagai Bentuk Upaya Paksa Penegakan Hukum Dalam Sistem Peradilan Pidana Di Indonesia." Supremasi Hukum: Jurnal Penelitian Hukum 29, no. 1 (2020).

Tampoli, Daniel Ch M. "Penghentian Penuntutan Perkara Pidana Oleh Jaksa Berdasarkan Hukum Acara Pidana." Lex Privatum 4, no. 2 (2016).

Trimarlina, Komang Dara, I. Nyoman Sujana, dan Ida Ayu Putu Widiati. "Implementasi Perlindungan Hak Asasi Manusia Terhadap Pemeriksaan Dalam Proses Penyidikan." Jurnal Analogi Hukum 1, no. 3 (2019): 411-416. 